\title{
Ti to Tomato, Tomato to Market
}

A decade of plant biotechnology

\author{
JAN LEEMANS
}

FIGURE 1.

Milestones in plant biotechnology.
10

CELEBRATING

A DECADE OF

EXCELLENCE the University of Gent (Belgium) and by Rob Fraley at the Monsanto Co. (St. Louis, MO), had independently "disarmed" the Ti plasmid of Agrobacterium tumefaciens, a bacterium that can transfer a part of its Ti plasmid-called T-DNA - into the plant genome. They had eliminated the crown gall disease-causing genes from the T-DNA while leaving the DNA transfer mechanism intact. Substituting foreign genes for the tumor-causing-genes allowed them to be trans-

Jan Leemans is at Plant Genetic Systems N.V., Jozef Plateaustraat 22, B-9000 Gent, Belgium.

\section{1}

\begin{tabular}{|c|c|}
\hline & Technical \\
\hline 1983 & $\begin{array}{l}\text { Ti plasmid disarmed }{ }^{1,2} \\
\text { Selectable marker for plants }{ }^{2-4}\end{array}$ \\
\hline 1985 & U.S. allows plant patents \\
\hline 1986 & Coat protein-mediated virus resistanc \\
\hline 1987 & $\begin{array}{l}\text { B.t.-based insect resistance }{ }^{24,25} \\
\text { Herbicide resistance }{ }^{17-20} \\
\text { Particle gun }{ }^{12} \\
\text { Cotton transformation }\end{array}$ \\
\hline 1988 & $\begin{array}{l}\text { Soybean and rice transformation } \\
\text { Ripening control in tormato } \\
\text { Antisense in plants }{ }^{40}\end{array}$ \\
\hline 1990 & $\begin{array}{l}\text { RAPD-analysis }{ }^{38,39} \\
\text { Corn transformation } \\
\text { Engineered male sterility }^{27}\end{array}$ \\
\hline
\end{tabular}

1992

Wheat transformation ${ }^{15}$

Modified carbohydrate composition ${ }^{31.32}$

Engineered fertility restoration ${ }^{28}$

Modified fatty acid profile ${ }^{29,30}$

\section{Commercial}

First field trial approved in the U.S. and Europe

USDAVAPHIS proposed guidelines for field testing

EC directive on deliberate release \& commercialization

Revised UPOV convention accommodates biotech products

Over 400 field tests performed worldwide USDAVAPHIS deregulates ripening controlled tomato

USDAVAPHIS proposes simpler procedure for field testing six crop species

FDA establishes framework for food safety evaluation

US patent on insectresistant plants issued ferred into the plant genome. In the absence of the TDNA genes, such plant cells could be regenerated into and fertile plants. ${ }^{1,2}$ The first practical system

genetic engineering of plants was thus assembled. rected by Mary Dell Chilton of Washington Univercontrol of a promoter isolated from one of the

The experiment showed not only that foreign genes and proteins could be expressed in plants but provided a widely used selectable marker gene fully ben tissues into which genes have successors and marker genes are used routinely in laboratories around the globe for transforming dicotylees. The research tools developed in 1983 not only marked the start of applied plant biotechnology research; they also enabled tremendous progress in the field of plant molecular biology. The use of transgenic plants became a powerful tool in analyzing gene function and studying gene regulation ${ }^{5}$ and protein targeting. ${ }^{6}$

\section{Transformation of crop plants}

The pioneering gene transfer experiments were performed in tobacco and other Solanaceous species. But within a decade, transformation protocols were established for all major crops. Agrobacterium is now used to transform soybean (the first of the " big four" crops-soy, maize, wheat, and rice), ${ }^{7}$ cotton, ${ }^{8}$ sugarbeet, ${ }^{9}$ sunflower, ${ }^{10}$ oilseed rape, ${ }^{11}$ and many vegetable crops. Extensive efforts have been undertaken to develop alternative methods to transform the world's most important cereal crops: corn, rice, and wheat, none of which are natural hosts for Agrobacterium.

The solution was direct gene transfer-not, as was thought for many years, into protoplasts--but into intact plant cells, which can be more efficiently regenerated into whole plants. Researchers at Cornell University (Ithaca, NY), 
The initial achievements in plant biotechnology were driven by the agrochemical industries and focused on improving agronomic performance. devised an instrument-the "particle gun," which is used to bombard plant cells with DNA-coated particles $^{12}$ - a technique known as "biolistics." The microprojectiles penetrate the cell walls and deliver DNA. Transgenic corn $(1990),{ }^{13}$ rice (1988), ${ }^{14}$ and wheat $(1992)^{15}$ were produced this way. Also in 1992 , researchers at Plant Genetic Systems (Gent, Belgium), obtained transgenic corn lines by electroporating DNA into enzymatically wounded immature embryos and into regenerable maize calli; ${ }^{16}$ the procedure is less genotype-dependent and requires a shorter period of tissue culture.

\section{Agronomic improvements}

Initial achievements in plant biotechnology were driven by the agrochemical industries and focused on improving agronomic performance. The $\$ 6$ billion global herbicide market attracted much attention. With the development cost for a new agrochemical rising rapidly, researchers looked to plant engineering as a way of gaining market share for a particular herbicide. Herbicide-tolerant crops were seen as a way of providing more effective, less costly, and more environmentally compatible weed control. The approach would allow reduced overall herbicide use by shifting to broad-spectrum herbicides with high unit activity, low toxicity, and rapid biodegradation.

Two approaches to herbicide tolerance have been followed. Tolerance to phosphinothricin, bromoxynil, and glyphosate has been achieved by expressing bac- terial genes encoding enzymes that inactivate the herbicide by acetylation, ${ }^{17}$ hydrolysis, ${ }^{18}$ or oxidation (Monsanto, unpublished results), respectively. Tolerance to glyphosate and to sulfonylurea, on the other hand, was engineered by introducing herbicide-insensitive mutant forms of the target enzymes. ${ }^{19-21} \mathrm{Herbi}$ cide-resistant transgenic crops have performed as expected in field tests. ${ }^{22}$

Gene transfer has been extensively used to enhance pest and disease resistance in crops. Researchers directed by Roger Beachy, now at the Scripps Research Institute (La Jolla, CA) and then at Washington University (St. Louis, MO), demonstrated that viral coat protein genes expressed in transgenic plants conferred resistance to virus infections. ${ }^{23}$ This approach has been successfully applied to a variety of virus/crop combinations. Virus resistance is important because it has positive effects on yield and may reduce the need for chemical control of the insect vectors that transmit the virus.

Reducing chemical insecticide use has been another important goal for plant biotechnology. Insect resistance was achieved in transgenic plants by expressing insecticidal proteins from Bacillus thuringiensis (B.t.). ${ }^{24,25}$ Insect-resistant cotton has been extensively field tested and will probably be the first crop with built-in insect resistance to be commercialized. Extensive screening of $B$. $t$. isolates has provided different $B$.t. genes encoding proteins that are highly active against various important pests such as the

\section{DYNABEADS $^{\circledR}$ M-280 STREPTAVIDIN You set the limits!}

Rapidly immobilize biotinylated nucleic acids onto Dynabeads M-280 Streptavidin.

Eliminate $100 \%$ of all contaminants through magnetic separation.

Perform specific DNA manipulations such as strand melting, elution and hybridization.

\section{GENOMI}

Allows PCR* directly on the solid phase.

Use one single tube for the entire application.

Obtain high sensitivity and reproducible results using monodisperse magnetic beads.

* The PCR process is subject of patents issued to the Cetus Corporation, Norwalk, CT

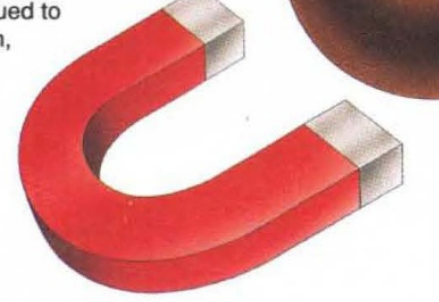

Patent Pending - Copyright 1992 Dynal $^{\circ}$

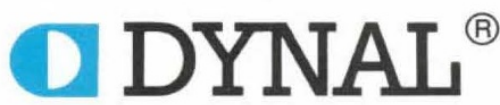

Making complicated bioseparations simple, rapid and reliable

DYNAL HEAD OFFICE: DYNAL AS, P.O.BOX 158 SKøYEN, N-0212 OSLO, NORWAY. TEL.: (+472) 529450 FAX.: (+472) 507015 TELEX: 79133 DYNAL N

DEUTSCHE DYNAL GmbH, Schaartor 1 Postfach 1119 65, W-2000 Hamburg 11

TEL: (040) 366811

FAX: (040) 366040
DYNAL (U.K) LTD., 26 Grove St. New Ferry, Wirral, L62 5 AZ

TEL: (051) 6446555 FAX: (051) 6452094
DYNAL INC., 475 Nothern Blvd. Great Neck, NY 11021 USA TEL: (516) 8290039 FAX: (516) 8290045
NIHON DYNAL K.K., 1-1-9 Atago Minato-Ku, TOKYO 105 TEL: (03) 34351558 FAX: (03) 34351526 
Colorado potato beetle. The insecticidal proteins interact with specific receptor molecules in the insect midgut and insects can have receptors for different B.t. proteins. ${ }^{26}$ Alternating or combining the use of several B.t. proteins that act through different receptors may be an important tool for managing the emergence of resistance and safeguarding the longterm usefulness of B.t.-based insect control.

Major improvements in crop performance can generally be achieved through the production of hybrid varieties. Crosses between inbred plants often result in progeny with higher yield, increased disease resistance, and enhanced performance in different environments compared with parental lines. To produce hybrid seed, seed producers control pollination to guarantee outcrossing and to prevent self pollination. Several crops still lack an efficient pollination control system. Researchers at PGS and UCLA (Los Angeles, CA), used genetic engineering to create sterile male plants by expressing ribonuclease genes under control of tightly regulated promoters. ${ }^{27}$ Subsequently, they used a ribonuclease inhibitor to create plants which, when crossed with sterile male plants, produce a hybrid crop in which fertility is fully restored. ${ }^{28}$ The method allows for the efficient production of hybrid oilseed rape, a major oil crop which today is grown as open-pollinated varieties. In corn, on the other hand, the method can replace the highly expensive practice of manual and mechanical removal of the tassel, the male reproductive organ, during seed production.

\section{Industrial Improvements}

Biotechnology's promise to improve the agrochemical performance of crops has lead several agrichemical companies to invest in the seed industry, sometimes by acquiring seed companies. Similarly, opportunities to improve the quality of the harvested product have lead large seed companies and food processors into a strategy of developing specialty crops with improved quality traits.

Researchers at Calgene (Davis, CA) have made significant progress in modifying plant oil composition. By introducing new enzymatic activities or by reducing the level of key enzymes in the biosynthesis pathway, fatty acid composition has been modified in oilseed rape. ${ }^{29,30}$ Similar approaches have been successful in modifying carbohydrate composition. Expression of an E. coli mutant gene encoding ADPglucosepyrophosphorylase in potato increased the starch level, ${ }^{31}$ while novel carbohydrates were produced when a bacterial cyclodextrin glucosyltransferase gene was expressed. ${ }^{32}$

The most widely publicized example of an engineered quality trait is the antisense inhibition of polygalacturonase in tomato. ${ }^{33,34}$ This and other approaches lead to fruits ${ }^{35-37}$ with enhanced shelf-life, delayed spoilage, and better processing characteristics that might ultimately improve flavor and texture. Calgene plans to commercialize the first genetically
Biotechnology's

promise to

improve the

agrochemical

performance

of crops has

lead several

agrichemical

companies to

invest in

the seed

industry....

\section{BIOREBA AG}

Gempenstrasse $8 \cdot \mathrm{CH}-4008$ BASEL/SWITZERLAND

Tel. 061 / $350455 \bullet$ Telex 963294 roth ch • Fax 061 / 356858

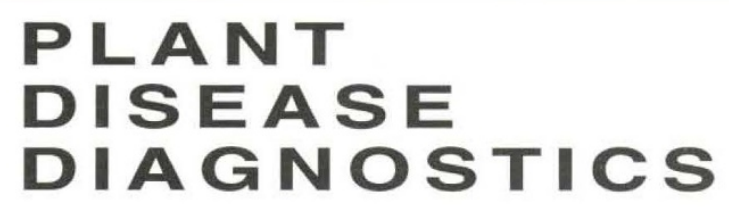

AGRI-CHECK ${ }^{\circledR}$

COMPLETE TEST KITS FOR

$2 \times 12$ OR 96 TESTS

EASY HANDLING

INCREASED SECURITY

FAST RESULTS

NO NEED FOR SOPHISTICATED LABORATORY EQUIPMENT

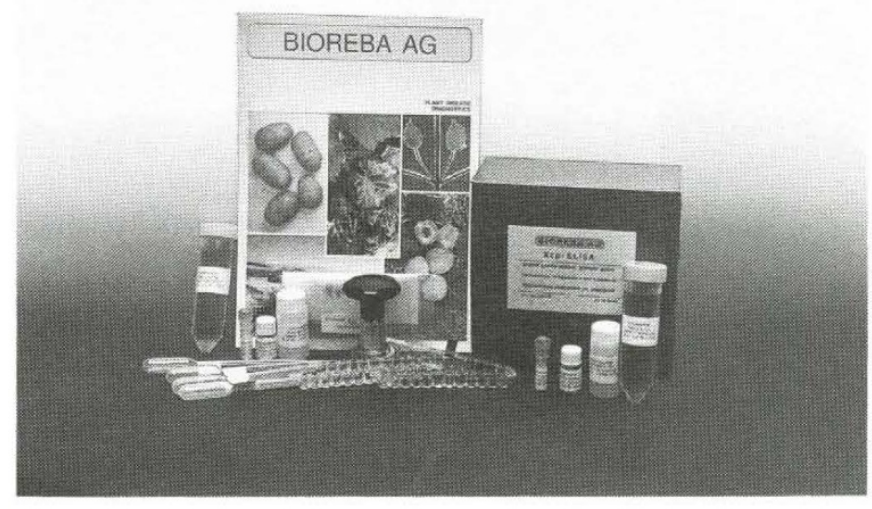

We are able to produce YOUR specific test kit - contact our $R+D$ manager!

BIOREBA Inc.

PO Box 2248, Chapel Hill, NC 27515 USA

Phone (919) 929-8190, FAX 929-8956

Contact: Mr. R. Scott Peoples
BIOREBA AG.

Baumgartenstrasse 5, D-7801 Ebringen / FRG

Phone/Fax 07664600255

Contact: Dr Ute Steffens 
As an adjunct

to to

conventional

breeding

programs,

molecular

breeding will increase the

efficiency of

progeny

selection and

considerably

shorten

development

times. engineered tomatoes this year.

These are the first reported successes in modifying plant metabolism through genetic engineering. More will follow as research groups devise strategies to improve the protein content of corn and soybean to enhance their nutritional quality as animal feeds, to modify the ratio of fatty acids in vegetable oils to improve stability, shelf-life, and cooking properties and to modify starches to address the specific needs of the food and chemical industry.

\section{Molecular breeding}

The detection and exploitation of naturally occurring DNA sequence polymorphisms is a significant new development in plant breeding. Restriction fragment length polymorphisms (RFLPs) have been used to create linkage maps and have lead to the development of indirect selection strategies for crop improvement programs. ${ }^{39}$ Researchers at Du Pont (Wilmington, DE) used PCR (polymerase chain reaction) technology to develop a new tool for marker-assisted selection in breeding programs: RAPDs (random amplified polymorphic DNA). ${ }^{38}$ Compared to RFLPs, RAPD analysis allows to detect polymorphisms at a higher frequency, is cost effective, and can be automated.

Molecular breeding benefits germ plasm improvement programs by providing the ability to identify, in the progeny of a genetic cross, recombinants that received a (trans)gene of interest while retaining the maximum genetic background of the elite recurrent parent. For hybrid crops, molecular breeding is used to predict the extent of heterosis by assessing the degree of divergence between candidate inbred lines. Germ plasm screening allows the breeder to correlate allele frequencies with biochemical or agronomical phenotypes to identify and introgress the loci that contribute to a particular trait. As an adjunct to conventional breeding programs, molecular breeding will increase the efficiency of progeny selection and considerably shorten development times.

\section{Issues for commercialization}

In the first decade of plant biotechnology, discoveries both in basic and applied research have lead to several prototype recombinant products, the stability and performance of which have been demonstrated in field trials. In the next decade, today's prototypes will be developed into commercial products. The speed and the extent of those commercial introductions will be determined by technical, commercial, and regulatory issues.

Technical issues include the transfer of engineered traits into agronomically relevant germ plasm and the adaptation of agronomic practices. Commercial issues include the size and structure of the seed market, the added value created by new genes, and the level of proprietary protection for new technology. In successful commercialization it will be costly to preserve the identity of the product from seed to its final end use. The new trait must contribute sufficient added value to offset these costs.

But it will be the regulatory climate that will influence the commercialization process the most. In the U.S., the regulatory agencies have developed a coordinated framework for regulating engineered crops and food products. In contrast, and despite European Community directives, national regulations in Europe are still variable and ill-defined. This lack of clarity and the associated regulatory costs could delay or limit the introduction of biotechnology products in the European Community.

Public perception of biotechnology might become the last but not least hurdle for commercializing plant biotechnology. Anti-technology groups are highly vocal and well-funded. While they represent directly only a minority of the public, their non-actual presentation of issues leads to public skepticism and threatens science-based regulations. The public must receive adequate information to put the tangible benefits and the perceived risks of biotechnology in perspective.

\section{Filling the information vacuum}

There is no doubt that the new tools such as transposon or T-DNA tagging, the availability of genetic and physical maps, YAC libraries, protein microsequencing, and especially concerted efforts to characterize the Arabidopsis genome will be effectively used to isolate genes that determine important plant phenotypes. By the end of its second decade, as an integrated and important component of agricultural and agro-industrial research, plant biotechnology will be helping produce economical and high-quality food and feed and contributing to sustainable agriculture on a global scale.

\section{References}

1. Zambryski, P. et al. 1983. EMBO J. 2: 2143-2150.

2. Fraley, R. et al. 1983. Proc. Natl. Acad. Sci USA 80: 4803-4807.

3. Herrera-Estrella, L. et al. 1983. Nature 303:209-213.

4. Bevan, M. et al. 1983. Nature 304:184-187.

5. Herrera-Estrella, L. et al. 1984. Nature 310:115-120.

6. Van den Broeck, G. et al. 1985. Nature 313:358-363.

7. Hinchee, M. et al. 1988. Bio/Technology 6: 915-921.

8. Umbeck, P. et al. 1987. Bio/Technology 5: 263-266.

9. D'Halluin et al. 1992. Bio/Technology 10: 309-314.

10. Everett, N. et al. 1987. Bio/Technology 5:1201-1204.

11. Radke et al. 1988. Theoret. and Applied Genetics 75: 685-694.

12. Klein, T. et al. 1987. Nature 327:70-73.

13. Gordon-Kamm, W. et al. 1990. The Plant Cell 2: 603-618

14. Toriyama, K. et al. 1988. Bio/Technology 6:1072-1074.

15. Vasil, V. et al. 1992. Bio/Technology 10: 667-674.

16. D'Halluin, K. et al. 1992. The Plant Cell 12:1495-1505.

17. De Block, M. et al. 1987. EMBO J. 6: 2513-2518.

18. Stalker, D. et al. 1988. Science 242: 419-423.

19. Comai, L. et al. 1985. Nature 317: 741-744.

20. Shah, D. et al. 1986. Science 233: 478-481.

21. Lee, K. et al. 1988. EMBO J. 7: 1241-1248.

22. De Greef, W. et al. 1989. Bio/Technology 7: 61-64.

23. Powell Abel, P et al, 1986. Science 232: 738-743.

24. Vaeck, M. et al, 1987. Nature 328: 33-37.

25. Fischhoff, D. et al. 1987. BiolTechnology 5:807-813.

26. Van Rie, J. et al. 1990. Science 247:72-76.

27. Mariani, C. et al. 1990. Nature 347:737-741.

28. Mariani, C. et al. 1992. Nature 357:384-387.

29. Voelker, T. et al, 1992. Science 257:72-74.

30. Knutzon, D. et al. 1992. Proc. Natl. Acad. Sci. USA 89:2624-2628.

31. Stark, D. et al. 1992. Science 258:287-291.

32. Oakes, J. et al. 1991. Bio/Technology 9:982-986

33. Sheehy, R. et al. 1988. Proc. Natl. Acad. Sci. USA 85 8805-8809.

34. Smith, C. et al. 1988. Nature 334:724-726.

35. Klee, H. et al. 1991. The Plant Cell 3:1187-1193.

36. Hamilton, A. et al. 1990. Nature 346:284-287.

37. Oeller, P. et al. 1991. Science 254:437-439.

38. Williams, J. et al. 1990. Nucl. Acids Res. 18:6531-6535

39. Tanksley, S. et al. 1989. Bio/Technology 7:257-263

40. Van der Krol, A. et al. 1988. Nature 333:866-869. 